\title{
Performing Repentance: (In)sincerity in Prodigal Son Drama and the Henry IVs
}

\begin{abstract}
The parable of the prodigal son is the most popular repentance narrative in early modern drama, yet the authenticity of these prodigals' repentances is frequently disputed. The truly repentant prodigal and posturing sinner are functionally identical on the early modern stage, and the parable was so renowned that the prodigal's repentance and forgiveness could not only be predicted, but expected and engineered. This essay compares prodigals' repentances across Eastward Ho, The London Prodigal, 2 If You Know Not Me You Know Nobody, and the Henry IVs. It argues that these plays exhibit discomfort with the outward display of repentance, the irrelevance of sincerity, and the viability of the parable as a repentance narrative. While some of these repentances have been discussed in isolation, their comparison allows for the examination of ambiguous repentances not as isolated incidents but a discernible trend in early modern culture, born from anxieties regarding the indistinguishability of feigned and 'true' performances of inward spiritual change. The authenticity of repentance, it emerges, cannot be determined, but repentance also need not be sincere to be accepted by a plays' community. The authenticity of repentance proves not only impossible to identify, but ultimately irrelevant to these plays' social worlds.
\end{abstract}




\section{Performing Repentance: (In)sincerity in Prodigal Son Drama and the Henry IVs}

'Well, I'll repent, and that suddenly, while I am in some liking.'

Falstaff (1 Henry IV, III.iii.4-5) ${ }^{\mathrm{i}}$

It is not unusual in literary scholarship for a play initially dismissed as dull and didactic to be later reclaimed as critical of the very notions it was originally condemned for extolling. These pronouncements are peculiarly common to certain prodigal son plays, in which the supposed (in)sincerity of the prodigal's repentance determines whether the play is judged didactic or satiric. The prodigal son plot, derived from Luke 15.11-32, ${ }^{\text {ii }}$ is the most widely adapted story of repentance and forgiveness in early modern culture. It provided a productive repentance narrative for many prose writers, ${ }^{\text {iii }}$ but was arguably put to its most challenging use on stage. ${ }^{\text {iv }}$ Some of these plays were side-lined by scholarship for being prudential, repetitive, and uninteresting, only to be later re-evaluated. The prodigals' repentances were long accepted as authentic and unchallenging to performative sincerity, and the plays consequently dismissed for dull didacticism; however, these repentances are being increasingly read as inauthentic postures and the plays as more critical of the moral values they were once thought to endorse. This shift is not, I argue, merely a consequence of evolving literary scholarship, but evidence of the unfeasibility of identifying authentic repentance. With reference to Reformed theology, this article compares the repentances of five prodigals in turn-of-the-century prodigal son drama: Quicksilver of Eastward Ho (1605), Jack Gresham of 2 If You Know Not Me You Know Nobody (1605), Flowerdale of The London Prodigal (c. 1604), Falstaff, and Prince Hal. Theology and religion have gained new prominence in early modern literary scholarship in recent years and the importance of their study is being recognised..$^{v}$ Drama offers a productive means of comparison with religious 
writings, as its performative nature can provide practical demonstrations of problems discussed theoretically in theology. The parable of the prodigal son becomes both the most popular narrative to frame repentance and the most effective means to destabilize its representation. Via its exhaustive reuse, the parable was transformed from a salvific narrative affirming God's infinite forgiveness and man's humility into a tool with the potential to engineer a façade of such humility. Yet these repentances, regardless of their sincerity, remain useful social acts. The authenticity of repentance proves not only impossible to identify, but irrelevant to these plays' social worlds.

The problem of identifying authentic repentance was central to Reformed theology. Lacking a Catholic preoccupation with ceremony, Protestants emphasised the inner experience of repentance. As Adrian Streete writes, 'If expressions of devotion and identification could no longer be officially mediated through outward signs, then interiority necessarily becomes the guarantor of sanctioned religious experience. ${ }^{\text {vi }}$ Many theologians offered formulaic conceptions of its definition and means to achieve it. Texts such as William Perkins' Of the Nature and Practise of Repentance (1595), Andreas Hyperius' The True Tryall and Examination of a Mans Owne Selfe (1586), and Jean Calvin's Institutes of the Christian Religion disassemble repentance into its constituent parts. The title of John Andrewes' Andrewes Caveat to Win Sinners is worth quoting in full for its instructive quality: A true and perfect way to win carelesse sinners (if there be but the least sparke of grace in them) unto speedy repentance, that in the end they may obtaine eternall life. ${ }^{\mathrm{vii}}$ In Calvin, the process of repentance is divided and catalogued, the experience of the soul translated into stages marked by literary taxonomy, by chapter and by subject. This systematic theology exacerbates the problematic mechanicity of the prodigal son plot: encoding repentance into formulae that can be reproduced and manipulated makes the parable an increasingly unreliable means for depicting sincere repentance. 
Calvin's work stresses the importance of mortification to true repentance: 'For when a man is brought to a true knowledge of sin, he begins truly to hate and abominate sin.' ${ }^{\text {viii }}$ Calvin always prioritizes the inward spiritual change and warns against displays of outward contrition. Of external repentance, he writes

it is not so much a turning to God as a confession of guilt, together with a beseeching of God to avert punishment and accusation. Thus, to 'repent in sackcloth and ashes' (Matt. 11:21; Luke 10:13) is only to evidence our self-displeasure when God is angry with us because of our grave offenses. Public, indeed, is this kind of confession, by which we, condemning ourselves before the angels and the world, anticipate the judgment of God. ${ }^{\text {ix }}$

For Calvin here, 'public' confession is a social act displayed before the profane 'world'. His objection is not that external repentance might be wholly performative; on the contrary, it is evidence of an internal component, self-displeasure, but without mortification it cannot constitute repentance. Paul Stegner identifies similar binary components to confession: 'The assurance of an effective confession thus contains two performances: an inward spiritual performance accessible only to the individual and God, and an outward social performance intended to reassure both the individual and others in order to facilitate a reintegration of the penitent into the community. ${ }^{\mathrm{x}}$ On stage, however, only this 'outward social performance' is present, and the penitent's reintegration into the community comprises the entirety of their reformation. Indeed, Debora Shuger asserts the purpose of public confession was social rather than spiritual: 'the Reformed tradition insisted on public confession, not for remission of sins but to strengthen and satisfy the community'. ${ }^{\text {i }}$ While an 'inward spiritual performance' might be essential for authentic confession, as Stegner argues, this is necessarily absent in theatrical 
performance. Every confession or repentance performed on stage functions analogously to these outward social performances, but its inward corollary remains absent. The successful player will be identical to the insincere confessor.

Even off-stage, authentic repentance proves difficult to identify. The Puritan Arthur Dent (1582) conceives of repentance with inextricable interior and exterior components. True repentance 'hath also another condition and that is, to alter and chaunge men from that they were before, not in the substance and proportion of the body: but in the qualities \& conditions of the minde. For whosoeuer hath truely repented, you shall by and by sée a moste marueilous, and wonderfull chaunge in him'. ${ }^{\text {ii }}$ Here, Dent sidesteps the problem of potentially insincere displays rather than presenting a viable solution. 'True' repentance, which is undefined, will inevitably change one's actions; this will be perceived by others and thus the interior 'wonderfull chaunge' can be confirmed. There is no anxiety in Dent's account about a possible disconnect between interior and exterior. Perkins (1590) is aware of the deceptive nature of outward repentance, striving to demonstrate 'HOW farre a man may go in the the profession of the Gospel, and yet be a wicked man and a reprobate.' ${ }^{\text {xii }}$ Elsewhere Perkins' (1606) solution is to emphasise the exterior profession and, should true inner repentance not follow, the Christian should 'with al speed use the meanes that they may be borne a new to the Lord, and may be inwardly guided by his holy spirite, to give obedience to his will'. ${ }^{\text {iv }}$ Even, then, among theological treatments of non-theatrical repentance, the authentic conversion proves slippery: it can only be identified by an external component, but such externality may be insincere.

It is worth situating these plays against the dramatic context that preceded them, as their potential satiricism draws on earlier, didactic works. The earliest prodigal son plays grew from the 'Christian Terence' tradition, created by Dutch schoolmasters of the sixteenth century who felt that Terentian comedy, though admirable in style, lacked Christian virtue 
and made for unsuitable teaching material. These writers, Macropedius and Gnapheus, married Terentian language with the plot of Luke 15.11-32 to create texts worthy of both Christian virtue and Terentian elegance. This produced, respectively, Asotus (c. 1510) and Acolastus (1529). Acolastus, translated into English in 1540, provoked similar prodigal son morality plays, including Pater, Filius, et Uxor (1530), Lusty Juventus (1550), Nice Wanton (1550), The Disobedient Child (1560), and Misogonus (1570). During the twentieth century, identification and interpretation of these plays developed a taxonomic approach defined by their adherence to the scriptural narrative. This trend was born with Charles Herford's short essay on 'the Prodigal Son cycle' in German works, which grounds the genre in a Lukan narrative. He breaks the plot into six narrative stages: prodigal sons are contrasted with industrious students, parents debate their sons' education, the prodigals riot, parents are consulted, the prodigals are disgraced - but these stages have little application to most sixteenth-century English plays. ${ }^{\mathrm{xv}}$

Herford's paradigmatic approach was taken up by subsequent commentators for English works. This methodology finds its most in-depth expression in the work of Alan Young and Ervin Beck. Young develops his own schema for prodigal son plays derived from ten elements of the narrative arc present in the Lukan parable, which serves as an index from which he identifies a list of thirty-five 'prodigal son plays'. ${ }^{\text {xi }}$ Beck critiques Young's lack of a 'conceptual framework' and ventures his own criteria with closer reference to the plays' heritage in New and Roman comedy. ${ }^{x v i i}$ Like Young, Beck hobbles his approach with insufficient justification of his generic criteria. He writes, 'The quintessential element in the paradigm is that a young man has departed from the values of his forebears - values which the play assumes he ought to reembrace'. Beck claims 'Prodigal-son comedy is conservative, not revolutionary, in its social implications', but we could venture any number of challenging or outright subversive examples - such as The Knight of the Burning Pestle (1607) or those 
plays that are the subject of this article - in rebuttal. ${ }^{\text {xviii }}$ This assumption that prodigal son plays are necessarily conservative is self-fulfilling. Defining prodigal son drama in relation to scripture both encourages an unproductively conservative taxonomy and promotes the assumption that prodigal son drama should or must extol Christian didacticism.

While the primacy of scripture is relevant to the morality plays, by the Jacobean period the dramatic tradition had sufficiently developed that the primary context for the parable was no longer scripture, but other plays. The explicitly biblical settings of the early morality plays give way to the social realities of city comedy. It is within this shift from didacticism to moral ambiguity that the plays that are the subject of this article are set, and their critical reception as didactic or satiric raises valuable questions about the interpretation of early modern repentance scenes.

Eastward Ho (1605) is the most well-known prodigal son play to have been reevaluated as more satiric than originally considered. A collaborative work performed at the Blackfriars by the Children of Her Majesty's Revels, Eastward Ho would have enjoyed a more sophisticated audience than those in attendance at The London Prodigal and Heywood's play. It is due to its status as intellectual private theatre fare that Eastward Ho is now firmly considered laudable satire; however, it is worth noting Jean Howard's argument for reading the irregularities in supposedly less sophisticated texts not as weaknesses but 'as traces of ideological struggle, of differences within the sense-making machinery of culture. ${ }^{\text {xix }}$ Furthermore, Eastward Ho itself was once condemned for the same supposedly naive moralism attributed to these other plays. R. W. Van Fossen presents a detailed overview of these assessments, spanning from the mid eighteenth century to the early twentieth. ${ }^{\mathrm{xx}}$ In the earliest of these accounts, Van Fossen argues it is clear critics saw the play as 'highly moral' ${ }^{x i}$ Highlights among Van Fossen's extensive list of critics who found the play didactic include Anthony Trollope, Algernon Swinburne, and Thomas Marc Parrott, who thinks it 'a 
conscious protest of [...] moralists against the new comedy of Middleton and Dekker' that dramatises 'the final triumph of the good'. ${ }^{x i i}$ Any contrary view remained a minority until the twentieth century, but the play is now unanimously accepted as a canny send-up of the prodigal son plot and pompous bourgeois ethics. ${ }^{\text {xiii }}$

This shift stems from conflicting readings of the prodigal Quicksilver's repentance scene. Quicksilver begins the play apprenticed to the moralistic Touchstone, who warns his apprentice to 'think of husks, for thy course is running directly to the prodigal's hogs' trough' (I.i.115-6). ${ }^{\text {xiv }}$ The workshy Quicksilver schemes and longs for a life of sumptuous expense, in which he can 'be like a gentleman, be idle'; he urges his fellow apprentice to prodigally 'Wipe thy bum with testones, and make ducks and drakes with shillings' (I.i.138-40). When his attempted journey to Virginia lands him on the Isle of Dogs, he is imprisoned and repents his dissolute and criminal actions. Building upon Peter Lake's argument that Eastward Ho parodies Puritan repentance, ${ }^{\mathrm{xxv}}$ David Kay argues, 'the cleverness of Chapman, Jonson, and Marston's parody consists in their ability to keep Quicksilver's performance close to the real thing, thereby emphasizing how the Puritan ideal of an inward spiritual conversion has already become a culturally determined script and exposing the ways we can manipulate and be manipulated by conventional formulations and moral paradigms. ${ }^{\text {xxvi }}$ However, there are comparable 'scripts' in theology. Quicksilver's performance of this script coincides with the similarly predetermined repentance that the parable necessitates, and both are destabilized. Kay explores how inward change can be suggestively feigned by outward performance; however, if Quicksilver's repentance is 'close to the real thing', what allows us to determine that it is not the 'real thing'? How does one dramatise an 'inward spiritual conversion'?

In the early morality plays, repentance is comprised of linguistic expression. To say 'I repent' is to repent. Its sincerity goes unquestioned regardless of the preceding behaviour of the prodigal, for the power of Christian redemption is so great as to overwhelm any 
interference between word and intent. In The Interlude of Youth, the prodigal Youth insists he will follow Riot 'in everything | And guide me after thy learning' (693-4); ${ }^{x x v i i}$ but then shortly claims, 'Here all sin I forsake | And to God I me betake | Good Lord, I pray thee have no indignation | That I, a sinner, should aske salvation' (739-41). Youth's proclamation of forsaking sin constitutes that forsaking in the speaking of it. Juventus of Lusty Juventus, once reminded of God's promises, proclaims 'From the bottom of my heart I repent my iniquity' and swears himself to God, and this constitutes his repentance (1119). ${ }^{\text {xxviii }}$ Repentance is confined to language.

Lorna Hutson writes, 'Evidential uncertainty was not a feature of the native English interlude, or morality play. ${ }^{\text {xxix }}$ It is not until the 1590 s, she argues, that dramatists became 'concerned with casting doubt on the reliability and probability of the signs and indications on which people base judgements about one another. ${ }^{\text {xxx }}$ The prodigal son plot and its problematic penitents made a productive frame for these strategies; a prodigal can lie about his repentance or abandon it, and the community must judge his authenticity. Scripture and Christian values may be deceitfully employed and manipulated by the prodigal, as in the use of deistic and familial oaths to emphasise untruths throughout The London Prodigal. The prodigal Flowerdale attempts to wheedle funds from his uncle by swearing on his own reputation, filial duty, and Christian subservience, the repetition of which only casts them as more untrustworthy: 'Unckle, where are you, Unckle?', 'By the Lord, in truth, Uncle', 'By your leave, Unckle', 'By my truth, Unckle' (I.i.90-102). ${ }^{\text {xxi }}$ When Flowerdale repents, his established mendacity and the lack of corroborating deed for that repentance stresses that this repentance may be another lie. Eastward Ho similarly destabilises the efficacy of scripture in its use of cliché, as the parable is contextualised in Touchstone's aphoristic idiolect as merely another stock platitude. Touchstone's prediction that Quicksilver 'is running directly to the prodigal's hogs' trough' is succeeded by his exhaustively repeated platitude to 'Work upon 
that now!' (I.i.115-7). This cliché contextualizes Touchstone's phrases in the same register of useless repetition, ideas rehashed so often they empty of meaning. Later, a disguised Quicksilver mocks Touchstone's predilection for ineffective maxims. He feigns praise of Touchstone's words and is 'proud to hear thee enter a set speech', then beseeches he continue. Touchstone obliges with the axiomatic "Ambition consumes itself with the very show' and another repetition of his favoured 'Work upon that now' (III.ii.141-54). It is within this register of exhausted meaning that we understand the prodigal son plot. When Touchstone concludes Quicksilver's repentance by reference to the parable, calling him 'The prodigal child reclaimed', doubt regarding the authenticity of Quicksilver's repentance taints the efficacy of that scriptural reference (V.v.223). Touchstone's moralism never curbed Quicksilver's prodigality, and there is little to suggest this final aphorism is truthful or effective. This final casting of Quicksilver as the prodigal child thus serves not to affirm the authenticity of his repentance, but to undermine it.

In Eastward Ho, the prodigal son plot belongs to a category of ineffectual moral cliché. Maren Donley's reading of these speech acts is illuminating; she argues, 'Touchstone's “thrifty sentences" function within the play as a merchant copy of Calvin's theological model'. ${ }^{x x i i}$ They have economic and moral value - as Donley writes, 'proper language signifies moral virtue and stands in for profitable economic conduct ${ }^{{ }^{\mathrm{xx} x i i i}}$ - but Quicksilver nonetheless ignores Touchstone's moralism. And yet, Quicksilver still performs the prodigal son plot, with a repentance corroborated by action. He writes letters of submission, converts and writes petitions for his fellow prisoners, cuts his hair, gives away his clothes, sings psalms all night, memorizes the entirety of The Sick Man's Salve, refuses the help of his lawyer Bramble because 'I commit my cause to Him that can succor me', and marries Sindefy, his punk, without complaint (V.iii.96-7). Of this repentance scene, Lake asks, 'Are not the speed and facility of his espousal of the conventional norms and forms of 
conversion and repentance [...] intended to imply that this too was a pose? ${ }^{\text {xxxiv }}$ What Lake calls a 'pose' and Kay calls a 'performance' emphasise the superficiality of Quicksilver's repentance, but this superficiality is problematized by the intensity of Quicksilver's efforts. He accurately and convincingly (to Touchstone) reproduces the appurtenances of repentance and corroborates that with substantive action. Flowerdale's repentances are disconnected from action, whereas Quicksilver's proclaimed repentance entails extensive endeavour.

This performance has little worth according to Calvin's metric. It is a 'sackcloth and ashes' repentance of which Quicksilver claims, 'the more openly I profess it, I hope it will appear the heartier, and the more unfeigned' (V.v.35-6). This line is troubling not only because of Quicksilver's concern to appear sincere, but also because it suggests the repeated performance of insincere repentance increases its credibility. If his sincerity remains indeterminable, the value of its performance must be constructed by the community. As Kay writes, 'Quicksilver's repentance, whether sincere or performed, restores his social credit'. ${ }^{\mathrm{xxv}}$ In Eastward Ho, the repentance is accepted; 'the performance creates the reality of humility as part of Quicksilver's character at that moment', Jennifer Clement argues. ${ }^{\text {xxxvi }}$ While Youth's sincerity was determined by the play's adherence to edenic semiosis, Quicksilver's is decidedly post-Babelic in its capacity to contain multiple unfixed meanings. Their (in) sincerity is decided by the readers of both literary scholarship and the community of Eastward Ho.

Clement's reading is optimistic. She argues, 'Humble behavior may well be feigned; yet such feigning, if taken as true, can lead to renewal and, at least, the promise of future virtue. [...] The play requires that hypocrisy not be sniffed out and exposed, but rather be accepted as true, whether it is or not. ${ }^{\text {'xxvii }}$ While Clement's reading suits Eastward Ho, it does not extend to all repentance scenes and the broader problem of inaccessible (in)sincerity. If Quicksilver's repentance is insincere then the moral is bleak: repentance no longer matters, 
only the convincing performance of it, and the prodigal son narrative has been repurposed from Touchstone's parable on the value of repentance to a tool to feign that repentance. But the ambiguity in determining whether that repentance is feigned or unfeigned arguably demonstrates a more potent anxiety: that the currency of repentance is valid in a mercantile social class regardless of its sincerity. It no longer matters if one truly repents.

Like Eastward Ho, The London Prodigal is a play much maligned for its supposed didactic conventionality that has been re-evaluated. A public theatre play, its audience was likely more receptive to didactic treatments of the prodigal son theme than that of Eastward Ho. That does not mean, however, that the play should be assumed absent of satiric or challenging elements. As Dieter Mehl speculates, 'It may be said that The London Prodigal deliberately casts doubt on a simplistic tradition of "prodigal-son comedy", qualifying the paradigm by its very title';xxviii however, such positive perspectives are a recent development. ${ }^{\text {xxix }}$ Likely due to unfavourable comparisons provoked by its misattribution to Shakespeare, the play was treated as offensively conventional. It was condemned by Alexander Pope as 'wretched', while William Hazlitt argued that, if the play was Shakespeare's, 'must have been among the sins of his youth. ${ }^{x l}$ Robert Lynam presents a fantastical scenario in which Shakespeare has The London Prodigal and other apocrypha 'consumed to ashes with great pleasure'. xli Tucker Brooke is more generous, praising the play for its 'richness of topical allusion', but still describes its subject matter as one of 'uninspiring mediocrity'. xlii Later critics more specifically address its generic conventionality: Alexander Leggatt finds it 'quite conventional' and 'moralizing', though praises its humanising elements and acknowledges it contains 'some criticism' of socio-economic themes; Young, meanwhile, charges it as guilty of 'heavy didacticism' xliii The play suffered this poor reputation until the end of the twentieth century, when it began to be recognised as possessing greater complexity. ${ }^{\text {xliv }}$ Critics have since advanced the position that The London Prodigal questions 
the characters' faith in Flowerdale's sincerity as well as the socioeconomic values of the play's urban environment. ${ }^{\text {xlv }}$ The plot concerns Old Flowerdale's unsuccessful attempts to engineer his son's repentance. This theme opens the play: Old Flowerdale, being himself a reformed prodigal - 'I my selfe ranne an unbrideled course till thirtie, nay, almost till fortie' (I.i.24-5) - takes his own reformation as evidence that his son will follow suit; and, furthermore, that this can be engineered. Having faked his death, Old Flowerdale pens his son an instructive letter in place of an inheritance. Flowerdale is displeased with its contents: "'Let him steale as much as he can, that a guilty conscience may bring him to his destinate repentance." I thinke he meanes hanging' (227-30). Flowerdale's sardonic dismissal of the possibility of repentance betrays a scepticism about the values exemplified by the prodigal son plot and an implicit refusal to follow the familiar arc of fall and redemption. Old Flowerdale is unfazed and plots to engineer his son's fall and ensuing repentance, but he repeatedly anticipates a repentance that does not come. After Flowerdale has rejected his father's letter and thrown out his new wife, Luce, to spend her dowry, Old Flowerdale appears to lose faith in the redemptive power of the prodigal son plot. Disguised, he confronts his unrepentant son: 'Goe! hang, beg, starve, dice, game, that when all is gone | Thou maist after dispaire and hang thy selfe' (III.iii.275-8). Luce remains spokesperson for Christian mercy, urging Old Flowerdale to forbear. But Old Flowerdale is 'greeve[d]' that his son 'beares his fathers name' (281). He tells his son to hang, echoing Flowerdale's morally bankrupt response to his father's letter. Both father and son lose faith in the morally ameliorative capabilities of the prodigal son plot.

Flowerdale's repentance, when it comes, lacks motivation and seems to serve the community more than a need for moral reform. Before this 'true' repentance he repeatedly feigns moral postures, denies several opportunities to repent, and always chooses swindling over honesty, even when penniless and starved. When he meets with the disguised Luce and 
she questions him socratically on the whereabouts of his wife, Old Flowerdale is sure his son's repentance will be forthcoming: 'If he have any grace, heele now repent' (V.i.182-3). Yet Flowerdale only responds with more falsehoods, claiming his wife is dead to win sympathy cash from this very wife he does not recognise. Flowerdale is then accused of Luce's murder, which Luce disproves by revealing herself. She charges Flowerdale to repent - and he does. Little has happened to change his perspective save the revelation that Luce is alive, which should matter little to Flowerdale, who was unmoved by reports of her death.

Edmondson points out that all Flowerdale must do to restore his fortune, reputation, and family 'is utter a few words of repentance', even if they are not sincere; ${ }^{x l v i}$ however, even more troubling is that Flowerdale's repentance does not appear to be clearly motivated by financial need. He is in penury for much of the play and could repent at any time, yet never does. His repentance in the final scene is urged by Luce, his (still disguised) father, his uncle, and the pressure is further heightened by the sympathetic interjections of Arthur, Oliver, and Weathercock. The repentance itself is restricted to a short speech:

I hope to win his favour,

And to redeeme my reputation lost:

And, Gentlemen, beleeve me, I beseech you:

I hope your eyes shall behold such change, As shall deceive your expectation.

Old Flowerdale deems this sufficient and forgives his son, though his prediction of his son's repentance - 'If he have any grace, heele now repent' (332) - uneasily repeats his earlier identical line (182-3), which failed to announce a repentance. While Flowerdale's repentance 
is insufficiently motivated, it is greatly encouraged by the other characters. Should he repent, much social disorder will be righted: Luce will have her husband, home, and reputation restored; Old Flowerdale will have his son back; the various debts Flowerdale has incurred will be paid off by his father; and all characters who have previously given Flowerdale financial support will have that support justified if it can be retroactively contextualised as having kept Flowerdale from starvation to enable his repentance. Flowerdale assures his father that he will 'hate the course [of prodigality] as hell', but these are just words, and his uncle's final line - 'Say it and do it, Cozen, all is well' - raises again the potential discrepancy between saying and doing that Flowerdale has consistently exhibited (437-9). The play ends, and these words remain uncorroborated by substantive action. The (in)sincerity of Flowerdale's repentance remains impossible to determine; however, even repentance uncorroborated by reformed action is of great social value. Flowerdale's unmotivated repentance contrasted against the high motivation of the community repositions the purpose of this repentance: it functions less to enable Flowerdale's moral reform and more to secure the community. Repentance is not, as it is in Eastward Ho, merely created by the community but is manipulated and even enforced by it. The London Prodigal offers no solution to these issues, and exhibits uneasy scepticism for the redemptive power of the parable in seventeenth century London.

Similar discomforts are present in 2 If You Know Not Me You Know Nobody (1605). A chronicle comedy of the public stage, Heywood's play 'attempt[s] to stage a version of history dominated not by the monarch but by exemplary figures from London's citizen class. ${ }^{\text {xlvii }}$ It is more sympathetic - even hagiographic - in its representation of the middle classes than The London Prodigal, and commands similarly low critical opinions. The Encyclopcedia Britannica describes it among other Heywood plays as 'theatrical mélanges employing two or more contrasted plots, poorly unified and liberally laced with 
clowning. ${ }^{\text {xlviii }}$ Little was said of the play before the millennium, and what was said is rarely complimentary. Irving Ribner finds it 'inconsequential', though considers its 'illustration of Heywood's characteristic bourgeois sentiment' worth noting. ${ }^{\text {xlix }}$ Young has similar opinions, citing its moralistic focus on 'the ill effects of idleness and prodigality'. ${ }^{1}$ Although these criticisms do not target the prodigal son plot specifically, the conventionality of Heywood's treatment of the plot is characteristic of these accusations of bourgeois sentiment. Charles Crupi speculates that the critical aversion to the play is due to 'a deep-rooted tendency to see popular plays as formulaic appeals to simple emotions and widespread beliefs. ${ }^{\text {,li }}$ These readings emphasise the play's conventionality, its sentiment, and its lack of emotional complexity. It is cast as a play with broad, middle-class morals, and lacking innovation charges similar to those levelled against Eastward Ho and The London Prodigal. Even if one agrees that the play is dully conventional, it is useful to ask why, a question explored in more productive readings of the play. ${ }^{\text {lii }}$ As Edward Bonahue writes, although both parts might be 'aesthetic failures by conventional measures of dramatic prowess, to dismiss them as imperfect literary artifacts is to miss an extraordinary opportunity to observe how the city wanted very badly to see itself and its activities.' Of part two, Bonahue writes, the play 'eras[es] the social problems most often associated with the wealth and transactions of the city. 'liii Whereas the machinations of Quicksilver and Flowerdale form the backbone of their respective plays and their repentances provide the climax, in Heywood's play the prodigal Jack Gresham is confined to a minor subplot. The play's treatment of this theme borders on perfunctory in comparison to its peers, but its reliance on tropes and its abrupt conclusion is why this formulation proves so useful to examine in contrast.

The prodigal son plot opens with Thomas Gresham chastising his nephew, Jack, for his dissolute behaviour. Gresham serves as both uncle and proxy employer as he arranges for Jack to follow a second apprenticeship, eliding paternal and professional roles. In a scene that 
recalls the opening of The London Prodigal, Gresham quickly establishes his son's objectionable behaviour: 'I have tane note of your bad husbandry, | Careless respect, and prodigal expence, | And out of my experience counsell you' liv Whereas some plays cite scripture to discourage the prodigal from his course (and in morality drama, such citation is the only requirement to do so), Heywood subverts the efficacy of Christian authority by casting Jack as the biblical mouthpiece. As his uncle accuses him of bawdy and deceitful practices, Jack manipulates scripture for his own purposes. In rebuking the charge that he has 'love[d]' a man's wife, Jack's reinterprets 'love' asexually, claiming 'I hold it parcell of my duty to love my neighbours. ${ }^{\text {lv }}$ When accused of having bought a dress for a sex worker, Jack insists 'the poore whore went naked, and you know the text commands us to cloath the naked' ${ }^{\text {lvi }}$ This perversion of scripture is a far cry from the edenic semiosis of the morality plays. Unlike the more bombastic Flowerdale, whose falsehoods are laid bare to the audience from the opening, Jack's witty rebukes are likely to generate admiration more than mockery. Gresham's own morality is ambiguous and his gullibility questionable, as he is 'proud | You can so probably excuse yourself' when Jack deftly justifies his behaviour. ${ }^{\text {lvii }}$ Jack performs a miniature of repentance to his father at the beginning of his arc, wherein he promises to throw off his wild behaviour and encourages his uncle's help in restraining him: 'I see my error; wilde youth must be bridled. Keepe me short, good uncle.' This performance climaxes with his clearly false claim that 'The only way to curbe a dissolute youth as I am, is to send him from his acquaintance; and therefore send me far enough, good Uncle: send me into France, and spare not. ${ }^{\text {, }}$ iii Once Gresham leaves, Jack proclaims his true intentions and we are faced with the familiar setup of an unruly prodigal seeking to cozen his elders and superiors.

Whereas Quicksilver's repentance takes up half of Eastward Ho's final act, Jack's is perfunctory. After promising to throw off his wild ways and assuring his debtors that he can pay his debts, Jack's many deceits can do little to commend his honesty. His final declaration 
of honesty is aimed at the wealthy Lady Ramsay, whom he attempts to wed to pay off his debts, as in the manner of A New Way to Pay Old Debts' (c. 1625) Welborn or Greene's Tu Quoque's (1611) Spendall. While The London Prodigal and A Trick to Catch the Old One (c. 1605) exploited this trope for cynical drama, Heywood's play sidesteps it entirely. Jack prefaces their meeting with a monologue of new promises. There is true pathos to his admission that 'before God, I have spent all, and am not worth anything', regardless of whether he can maintain his contrition. He proclaims, 'I have neither money nor credit, as I am an honest man' and that he will 'forswear all women but her.' Yet this repentance is, like Flowerdale's, confined to declaration. His vow to never kiss another man's wife falls especially flat as he has falsely defended this charge before, as well as having exploited false accusations of Hobson's infidelity. He debates which mode to affect and ironically decides on 'honest Jack, in thine own honest humour. Plain dealing's a jewell, and I have us'd it so long, I am next door to a beggar'. lix

What, then, is 'honest Jack'? The concept is never established and, rather, is continually subverted. Every previous pose of honesty has been proven false. Jack's wooing of Lady Ramsay is peppered with asides - his repeated 'I shall have her sure' and farcical conversation carried on with the debtors - which undercut his professed honesty. ${ }^{1 \mathrm{x}}$ His open admission of his poverty, acknowledgement of her wealth, and desire for the latter to alleviate the former parodies the widow-prodigal romance trope. These parodic elements are heightened by his interjectory comments to the debtors throughout the wooing, a farce that verbally interweaves the figurative lattice of financial and romantic energies. Lady Ramsay declines the marriage proposal, but agrees to pay Jack's debts. Separately, however, she makes him a gift of twenty pounds of gold 'for your paines', exchanged directly for his marriage proposal discrete from the debt-paying. ${ }^{\text {lxi }}$ She promises to marry Jack at a later date, as she claims she would rather marry one that 'seeme[s] thus wild, | Then one that hath worse 
thoughts, and seemes more mild', but this remains as uncertain as Jack's claimed repentance. Since his promises of honesty were predicated upon his marrying we may be more sceptical of their sincerity given the marriage has not occurred. Jack's final thoughts are fixed on the wealth encoded by Lady Ramsay's romantic token: 'if I grow rich by the helpe of this, | Ile say I rose by Lady Ramseys kiss'. xii

Thus concludes Jack's arc. Jack's repentance is not contextualised by the community, with only Lady Ramsay providing a response. He never meets with his father and thus does not apologize for his trespasses. Without a reception for this repentance, we find Jack's plot

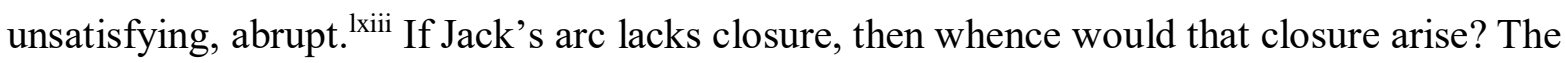
tropes invoked in Jack's final scene fail to answer if he will reform - but this is not so different from the end of Eastward Ho or The London Prodigal. These repentance arcs are not criticized for abruptness because they conclude with those repentances being contextualized within the community. This not only offers closure but also emphasizes the importance of communal hermeneutics in understanding those repentances. We read these repentances via the readings of other characters. Without the contextualising community, Jack's repentance remains a question mark.

In the Henry IVs, the two-part structure further clarifies the problematic performance of repentance. When rejecting Falstaff and assuming his place as king of England, Hal retroactively contextualizes the events in Part I (including his repentance to his father and redemptive defeat of Hotspur) as part of an unrepentant 'dream' from which he does not awaken until the final scene of Part II: 'I have long dreamt of such a kind of man, | So surfeitswelled, so old, and so profane; | But being awake, I do despise my dream' (V.v.49-51). According to Hal here, this awakening marks the watershed of repentance and commencing reformation; however, there are other moments that may be interpreted as similar watersheds. To what extent does Hal's retroactive relegation of these acts to his unrepentant dream-self 
invalidate those previous scenes of repentance? How does one understand the apparent arc of repentance and reformation of Part I given Hal's rejection of it in Part II?

The Henry IVs' literally ambiguous structure facilitates uniquely complex treatments of the problem of authentic repentance. The plays are neither wholly independent nor can they be unified. As Harold Jenkins writes, 'The two parts are complementary, they are also independent and even incompatible. 'xiv The 'structural problem' of the Henry IVs has become a question of literary methodology rather than of editorial history; there is little evidence to suggest the two plays were considered as two halves of a whole in Shakespeare's lifetime, and attempts to unify them have won little favour. I am sympathetic to Paul Yachnin's argument than unified readings of these texts are the result of a 'mistaken attempt to force the idea of aesthetic unity upon the genre of Shakespeare's Histories'. ${ }^{1 x v}$ Central to the structural problem and Yachnin's argument is Hal's double redemption. In both plays he riots and repents, which Yachnin sees as a 'crucial discontinuity', ${ }^{1 x v i}$ and it is one defenders of the 'unity' position have struggled to resolve.

I want to reframe Hal's continually revised redemption. Hal is indeed revisionist to his own redemption, as he revises his promise to his father to 'Be more myself' in (III.iii.92) and abandons his expected post-Shrewsbury reformation come Part II. For Yachnin, 'Hal's actions at Shrewsbury are recast as an actorly performance of a reformation rather than a reformation itself'. ${ }^{\text {xvii }}$ I argue that Hal's revisionism is insufficient evidence to read Hal's repentances as merely performance, or that 'an actorly performance of a reformation' is exclusive to 'reformation itself'. Instead, the potential performativity of Hal's repentance and the discontinuity it engenders may be more productively taken as evidence for the instability of repentance. That a repentance can function simultaneously as a genuine and total repentance, a genuine but partial repentance, and a feigned performance depending on the perceived (in)compatibility of the two parts of Henry IV demonstrates the great flexibility and 
fragility of repentance. The 'authenticity' of Hal's Part I repentance is impossible to determine. Hal depicts his riot as both separate to his authentic self - it is a 'loose behaviour' he will 'throw off' to reveal an essential authenticity, to become 'more myself' (1 Henry IV, I.ii.205, III.iii.92) - and as something innate only lost through transformation, for he instructs Falstaff to 'Presume not I am the thing I was' (2 Henry IV, V.v.56). Hal's reformation at the end of Part I is overturned by his return to Eastcheap in Part II, but there is no evidence of its falsity in the first play. His Part I repentance depends, like Schrödinger's cat, on whether we open the box of Part II.

In the familiar prodigal son plot, repentance and forgiveness are the always predictable consequences to riot - providing that riot is appropriately contextualised. This predictability enables Hal and Falstaff to each attempt to engineer an arc of rebellion, repentance, and forgiveness, with each playing the role of prodigal. Where Falstaff fails, Hal succeeds. Despite their differences, these characters' uses of the prodigal son plot are troublingly isomorphic. Hal intends to repent - to 'redeem[...] the time' (I.ii.210) - at which he appears to succeed in both plays. He begins each play in riot, and ends Part I and II a reformed prince and king, respectively. Before addressing Hal's relapse and the plays' discontinuities, I will interrogate this idea of intended or deferred repentance.

Any intended repentance is a deferred repentance. For some critics, Hal never needs to reform, or else begins the play having already reformed. ${ }^{\text {lxvii }}$ This school does not read Hal's riot as immoral but rather, being as they are part of a narrative Hal has constructed to rise 'glitt'ring o'er my fault', as evidence of his political virtue (I.ii.210). For other critics, Hal's riots serve Machiavellian ends. ${ }^{\text {xix }}$ Others argue that Hal's speech serves to justify procrastinating in lackadaisical riots. ${ }^{\text {lxx }}$ But the problems of Hal's deferred repentance can be better understood when contextualised within Calvinist theology. A dilemma emerges in the Calvinist understanding of repentance, for God's infinite forgiveness should always redeem 
an elect sinner regardless of how late or low they have fallen (as displayed by the parable), but allowing indefinitely deferred repentance results in lives of sin concluded with deathbed repentances. Theologians exhort immediate repentance, criticise the inauthenticity of deathbed confession, and define repentance as something that cannot be deferred; as Perkins writes (1600), 'The time of repentance is the time present, without any delay at all'. lxxi Repentance ought to be an ongoing process, constantly engaged and renewed, 'a constant turning of man in his whole life from all his sinnes, unto God' . ${ }^{x x i i}$ In Calvin, 'When this thought is deeply and thoroughly fixed in mind - that God will someday mount his judgment seat to demand a reckoning of all words and deeds - it will not permit the miserable man to rest nor to breathe freely even for a moment without stirring him continually to reflect upon another mode of life whereby he may be able to stand firm in that judgment. 'lxxiii These exhortations take their cue from Matthew 3:2, 'Repent: for the kingdome of heaven is at hand', but the scripture says little on the efficacy of immediate versus deathbed repentances.

The difficulty of identifying authentic repentance not only in others but in oneself presents another concern. As Andrewes writes (1621), 'Many presume to describe it [repentance], though few know it: many can talke of it, but few walke in it; many speake of it, but few feele it; and many thinke they have caught it, when they have but the shaddow of it' lxxiv Despite the title of this text promising to be 'perfectly guiding [...] in the right way' of repentance, Andrewes' treaty is devoted more to defining what repentance is not and its elusiveness than to how to attain it. All agree repentance should not be deferred. Andrewes devotes a section to the importance of immediacy, for 'The time of repentance is double; First it must be done prese[n]tly, without delay: Secondly, continually, every day. It must bee done speedily without delay', and 'late repentance is seldome or never true repentance.' ${ }^{\text {xxv }}$ Such theological writings have particular application to the Henry IVs; as Michael Davies writes, Hal's rejection of Falstaff does not reflect Puritanism but rather 'the common godly discourse 
on the common sins of Elizabethan England as propounded from the popular pulpit.' ${ }^{\text {lxxvi }}$ There is a desperation to these texts: repentance must be defined so the reader can attain salvation, but repentance must also be engaged in immediately and constantly. One cannot risk delay.

In contrast to this frantic urgency, Hal defers repentance with mellow indulgence: 'I [...] will a while uphold $\mid$ The unyoked humour of your idleness' and will abandon riot only when he 'please again to be himself' (1 Henry IV, I.ii.192-7). In this sense, Falstaff's deferred repentance adheres more closely to the theological writings. He may fail to repent, but he acknowledges the vitality of doing so - 'I must give over this life, and I will give it over' ( 1 Henry IV, I.ii.95-6) - even if he never actualises those promises. Hal's declaration to 'Redeem[...] time when men think least I will' appears to be a rejection of deferral, but its future grammar renders it a form of deferral itself. As Paul Jorgensen demonstrates, this reference to Ephesians 5.16 does not denote atonement for past sins but constant, active selfassessment of one's potential sins. ${ }^{\text {lxxvii }}$ Hal defers.

While critics usually relegate deferring repentance to Falstaff, with his penchant for procrastination both spiritual and otherwise, Hal's and Falstaff's behaviours concerning repentance are often functionally identical. For Davies, Falstaff is emblematic of the deferral and carnality so condemned by Elizabethan Calvinists; I would go further and posit that, though lacking in carnality, Hal is guilty of the same deferral. A useful point of comparison is their understanding of debt. Falstaff defers death as he does his debts - 'do not speak like a death's-head, do not bid me remember mine end' (2 Henry IV, II.iv.236-7) - and responds to Hal's charge that he 'owest God a death' with 'Tis not due yet. I would be loath to pay him before his day' (1 Henry IV, V.i.126-7). But as Perkins writes, 'if a man repent when he cannot sinne as in former time, as namely in death: then hee leaves not sinne, but sinne leaves him'. ${ }^{\text {xxviii }}$ Falstaff defers both financial and spiritual debts, refusing the Lord Chief Justice's 
insistence that he pay Mistress Quickly 'the debt you owe her, and unpay the villany you have done her: the one you may do with sterling money, and the other with current repentance' (2 Henry IV, II.i.120-3). The articulation of spiritual debt via a financial register is frequently engaged by Hal, for whom rejecting riot and returning to his father is to pay the 'debt I never promisèd' (1 Henry IV, I.ii.206). However, while it is true that Falstaff defers debt repayment and that Hal repays debts compulsively, and it is also true that Falstaff defers repentance whereas Hal succeeds in both triumphing at the Battle of Shrewsbury and casting off Falstaff once he becomes king, Hal crucially also defers repentance. Falstaff and Hal both consign their repentances to futurity, with Falstaff's 'I'll repent' (1 Henry IV, III.iii.4) and the 'I will' of Hal's intend to 'Redeem[...] time when men think least I will' (I.ii.214).

These instabilities should not be regarded as abnormalities in the early modern understanding of repentance, but an inherent facet of it. 'Authentic repentance' cannot be grasped. Interiority proves irrelevant to performed repentance and the meaning of that repentance is foisted upon the repentant by the community or the audience as is seen fit. When a play ends - as Eastward Ho, The London Prodigal, 2 If You Know Not Me You Know Nobody do - with the reformation of a rakehell, the play ending and the theatre emptying safeguards us against any lapse in the prodigal's behaviour. If the repentances of Quicksilver, Flowerdale, Jack Gresham, and other prodigals seem questionable, the ease with which Hal's repentances can be destabilised is made more potent by how often they are taken as authentic and stable. The plays' dualistic structure makes concrete the possibilities suggested by these other plays. A prodigal's most convincing repentance may not preface a lasting reformation. And most troublingly, it is not merely that an inauthentic repentance functions identically to an authentic repentance, but that no such distinction can be made. Hal embodies the terrible fragility of the search for 'true' repentance. Even if it seems to have been achieved, it may be immediately subverted or empty of corroborating action; it may be just a dream. 
There is something paradoxical about the parable of the prodigal son. The parable's enduring appeal lies in the contrast between the wretched prodigal and the unconditional forgiveness of his father, but this contrast relies on the prodigal's ignorance of that forgiveness. The son 'was lost, but he is founde' (Luke 15.32): prodigals must be lost for mortification, quickening, repentance, and reconciliation to occur. The prodigal who returns expecting forgiveness is neither lost nor mortified. But how can despair occur to the Christian who believes in the redemptive power of Christ? The parable becomes self-defeating: it only has use to those in the midst of mortification, and is supremely unhelpful to those who are not. Once a community has accepted the values of the parable, the parable can even be used to contextualise and justify riot.

Come the mid-seventeenth century, there are few prodigals for whom the arc of riot, repentance, and forgiveness does not leave them with a net benefit. The plot exists as either empty cliché, or justification for the very immorality it ought to warn against. The scripture itself points towards this idea: 'these manie yeres have I done thee service, nether brake I at anie time thy co[m]mandment, \& yet thou never gavest me a kid that I might make merie with my frie[n]ds' (Luke 15.29). To fall and be redeemed proves better - socially, financially, and even morally - than to never fall.

\footnotetext{
i Shakespeare quotations are from William Shakespeare, The Oxford Shakespeare: The Complete Works, ed. by Stanley Wells and Gary Taylor, 2nd ed. (Oxford: Oxford University Press, 2005).

${ }^{\text {ii }}$ Scripture quotations are from The Bible and Holy Scriptures (Geneva: 1560).

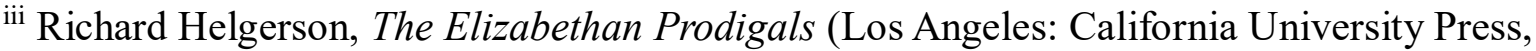
1976).

iv For definitions of 'prodigal son plays', see Charles Herford, Studies in the Literary Relations of England and Germany in the Sixteenth Century (London: Frank Cass and Co. Ltd., 1966), 152-64; John Dover Wilson, The Fortunes of Falstaff, 5th ed (Cambridge: Cambridge University Press, 1979), 19; Madeleine Doran, Endeavors of Art (Madison:
} 
University of Wisconsin Press, 1954), 165; Muriel Bradbrook, The Growth and Structure of Elizabethan Comedy (Cambridge: Cambridge University Press, 1979), 37-8; Robert Y. Turner, 'Dramatic Conventions in All's well That Ends Well', PMLA, 75 (1960), 497-502, (497); Alan Young, The English Prodigal Son Plays, ed. by James Hogg (Salzburg: Universität Salzburg, 1979); and Ervin Beck, 'Terence Improved: The Paradigm of the Prodigal Son in English Renaissance Comedy', Renaissance Drama, New Series, VI (1973), 107-122.

${ }^{v}$ Notable recent publications include Debora Shuger, The Renaissance Bible: Scholarship, Sacrifice and Subjectivity (Berkeley: University of California Press, 1994); Brian Cummings, The Literary Culture of the Reformation: Grammar and Grace (Oxford: Oxford University Press, 2007); Beatrice Groves, Texts and Traditions: Religion in Shakespeare, 1592-1604 (Clarendon Press, 2007), Hannibal Hamlin, The Bible and Shakespeare (Oxford: Oxford University Press, 2013), Early Modem Drama and the Bible: Contexts and Readings, 15701625 ed. by Adrian Streete, (Basingstoke: Palgrave Macmillan, 2012); The Oxford Handbook of the Bible in Early Modern England, c. 1530-1700, ed. by Kevin Killeen, Helen Smith, Rachel Willie (Oxford: Oxford University Press, 2015).

${ }^{v i}$ Adrian Streete, Protestantism and Drama in Early Modern England (Cambridge:

Cambridge University Press, 2009), 35.

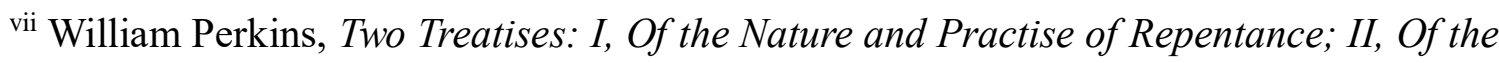
Combat of the Flesh and Spirit ([Cambridge]: 1595); Andreas Hyperius, The True Tryall and Examination of a Mans Owne Selfe (London: 1586), in Early English Books Online, $<$ http://gateway.proquest.com/openurl?ctx_ver=Z39.882003\&res_id=xri:eebo\&rft_id=xri:eebo:citation:180867169> [accessed 19 February 2016]; John Calvin, vol. 1 of Institutes of the Christian Religion, ed. by John T. McNeill, trans. by Ford Lewis Battles (London: S. C. M. Press, 1961); John Andrewes, Andrewes Caveat to Win Sinners (London: 1631).

viii Calvin, 597. III.3.5.

ix Ibid., 611-2. III.3.18.

x Paul D. Stegner, “"Try What Repentance Can”: Hamlet, Confession, and the Extraction of Interiority', Shakespeare Studies, 35 (2007), 105-29 (111).

${ }^{x i}$ Debora Shuger, Habits of Thought in the English Renaissance: Religion, Politics, and the Dominant Culture (Toronto: University of Toronto Press, 1997), 39.

${ }^{x i i}$ Arthur Dent, A Sermon of Repentaunce (London: 1582), fol. B2r.

xiii William Perkins, A Treatise Tending unto a Declaration Whether a Man Be in the Estate of 
Damnation or in the Estate of Grace (London: 1590), 1.

xiv Ibid., 27.

${ }^{x v}$ Charles Herford, Studies in the Literary Relations of England and Germany in the

Sixteenth Century (London: Frank Cass and Co. Ltd., 1966), 152-64.

xvi Young, viii.

${ }^{\text {xvii }}$ Ervin Beck, 'Prodigal son comedy: the continuity of a paradigm in English drama, 1500-

1642' (unpublished doctoral thesis, The University of Indiana, 1972) and 'Terence Improved', 107-122 (109).

xviii Ibid., 112.

xix Jean Howard, The Stage and Social Struggle in Early Modern England (London:

Routledge, 1994), 7.

${ }^{\mathrm{xx}}$ Van Fossen, 19-25.

${ }^{x x i}$ Ibid., 21.

xxii Thomas Marc Parrott, The Plays and Poems of George Chapman, Vol. 2 (London:

Routledge, 1914), 3 vols., 840.

${ }^{x x i i i}$ R. W. Van Fossen, 'Introduction', Eastward Ho (Manchester: Manchester University

Press, 1979), 1-58 (37); Peter Lake, The Antichrist's Lewd Hat (London: Yale University

Press, 2002), 405; Young, 251.

${ }^{\text {xxiv }}$ George Chapman, Ben Jonson, John Marston, Eastward Ho, ed. by R. W. Van Fossen (Manchester: Manchester University Press, 1979).

${ }^{x x v}$ Lake, 394-407.

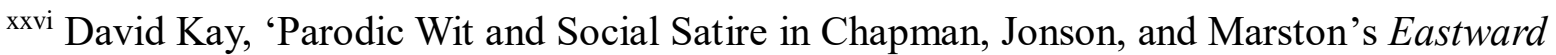
Ho!', English Literary Renaissance 42.3 (2012), 391-424 (418).

xxvii 'The Interlude of Youth', Two Tudor Interludes, ed. by Ian Lancashire (Manchester:

Manchester University Press, 1980), 99-152.

xxviii R. Wever, 'Lusty Juventus', Four Tudor Interludes, ed. by J. A. B. Somerset (London:

Athlone Press, 1974), 97-127.

${ }^{x x i x}$ Lorna Hutson, The Invention of Suspicion: Law and Mimesis in Shakespeare and Renaissance Drama (Oxford: Oxford University Press, 2007), 18.

xxx Ibid., 13.

xxxi 'The London Prodigal', The Shakespeare Apocrypha, ed. by C. F. Tucker Brooke (Oxford: Clarendon Press, 1908), 191-218. 
xxxii Maren L. Donley, 'The Mechanics of Virtue: Quicksilver's "Repentance," the Test of the Audience, and Social Change in Eastward Ho', Renaissance Drama, 41.1/2 (2013), 22-55 (53).

xxxiii Ibid., 34.

${ }^{\text {xxiv }}$ Lake, 405.

${ }^{\text {xxxv }}$ Kay, 394.

xxxvi Jennifer Clement, Reading Humility in Early Modern England (Farnham: Ashgate, 2015), 54 .

xxxvii Ibid.

xxxviii Dieter Mehl, 'The London Prodigal as Jacobean City Comedy', Plotting Early Modern

London, ed. by Dieter Mehl, Angela Stock, Anne-Julia Zwierlein (Farnham: Ashgate, 2004), $165-176(174)$.

${ }^{\text {xxxix }}$ Alexander Pope, 'Mr. Pope's Preface', Prolegomena to the Dramatick Writings of Will. Shakespeare, I (London: John Bell, 1788), 6-26 (23); William Hazlitt, Characters of Shakespeare's Plays, 3rd ed (London: John Templeman, 1838), 316; Robert Lynam, vol. XV of The British Essayists (London: J. F. Dove, 1827), 100; C. F. Tucker Brooke, 'Introduction', The Shakespeare Apocrypha (Oxford: Clarendon Press, 1918), xii, xxx; Alexander Leggatt, Citizen Comedy in the Age of Shakespeare (Toronto: Toronto University Press, 1974), 34-6; Young, 234-5.

${ }^{\mathrm{xl}}$ Alexander Pope, 'Mr. Pope's Preface', Prolegomena to the Dramatick Writings of Will. Shakespeare, I (London: John Bell, 1788), 6-26 (23); William Hazlitt, Characters of Shakespeare's Plays, 3rd ed (London: John Templeman, 1838), 316.

${ }^{x l i}$ Robert Lynam, The British Essayists; with Prefaces Biographical, Historical, and Critical, Vol. XV, (London: J. F. Dove, 1827), 30 vols., 100.

xlii C. F. Tucker Brooke, 'Introduction', The Shakespeare Apocrypha (Oxford: Clarendon Press, 1918), xii, xxx.

xliii Alexander Leggatt, Citizen Comedy in the Age of Shakespeare (Toronto: Toronto University Press, 1974), 35; Young, 234-5.

xliv Richard Proudfoot, 'Shakespeare's Most Neglected Play', Textual Formations and Reformations, ed. by Laurie E. Maguire and Thomas L. Berger (London: Associated University Press, 1998), 149-57; Edmondson; Mehl, 'The London Prodigal', 165-176. ${ }^{x l v}$ Ervin Beck, 'Prodigal son comedy: the continuity of a paradigm in English drama, 15001642' (PhD diss., University of Indiana, 1972), 154; Alan McFarlane, 'The Representation 
and Development of the Early Modern Subject in the Disguised-Ruler Plays, 1604-6' $(\mathrm{PhD}$ diss., University of Aberdeen, 1997). 262-3.

xlvi Edmondson, 67.

xlvii Jean Howard, 'Competing Ideologies of Commerce in Thomas Heywood's If You Know Not Me You Know Nobody, Part II', The Culture of Capital: Property, Cities, and Knowledge in Early Modern England, ed. by Henry Turner (New York: Routledge, 2014), 163-82 (178). xlviii ‘Thomas Heywood’, Encyclopædia Britannica, Encyclopædia Britannica, inc. [online], August 17, 2011: (accessed April 17, 2017).

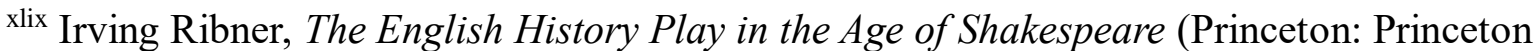
University Press, 1957), 221.

${ }^{1}$ Young, 238-40.

${ }^{\text {li }}$ Charles W. Crupi, 'Reading Nascent Capitalism in Part II of Thomas Heywood's If You Know Not Me, You Know Nobody', Texas Studies in Literature and Language, 46.3 (2004), 296-323 (297).

lii See reevaluations of this play in Crupi; Anita Gilman Sherman, 'The Status of Charity in Thomas Heywood's If You Know Not Me You Know Nobody II', Medieval and Renaissance Drama in England, 12 (1999), 99-120; Barbara Sebek, ““After My Humble Dutie Remembered": Factors and/versus Merchants', Emissaries in Early Modern Literature and Culture, ed. by Gitanjali Shahani and Brinda Charry (Surrey: Ashgate, 2009), 113-28; Linda Woodbridge, 'The Peddler and the Pawn: Why Did Tudor England Consider Peddlers to Be Rogues?', Rogues and Early Modern English Culture, ed. by Craig Dionne, Steve Mentz (Ann Arbor: University of Michigan Press, 2004), 143-70 (158-66); Howard, 'Competing Ideologies'.

liii Edward Bonahue, 'Social Control, the City, and the Market: Heywood's If You Know Not Me, You Know Nobody', Renaissance Papers (1993), 75-90 (90).

liv Thomas Heywood, The Second Part of, If You Know Not Me, You Know No Bodie (London, 1606), A3r.

${ }^{1 \mathrm{v}}$ Ibid., A3v.

lvi Ibid.

lvii Ibid.

lviii Ibid., A4v.

lix Ibid., I1v.

Ix Ibid., I2v.

lxi Ibid., I3r. 
lxii Ibid.

lxiii See Dieter Mehl, 'The Late Queen on the Public Stage', Queen Elizabeth I: Past and Present, ed. by Christa Jansohn (Münster: LIT Verlag, 2004), 153-71 (168).

lxiv Harold Jenkins, 'The Structural Problem in Shakespeare's Henry IV', King Henry IV, Parts 1 and 2: A Casebook, ed. by G. K. Hunter (London: MacMillan Press, 1970), 155-173 (171).

${ }^{\text {lxv }}$ Paul Yachnin, 'History, Theatricality, and the "Structural Problem" in the Henry IV Plays', Philological Quarterly, 70.2 (1991), 163-79 (163).

Ixvi Ibid., 167.

lxvii Yachnin, 170.

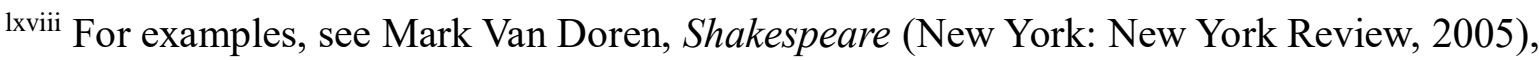
98; Keiji Aoki, Shakespeare's Henry IV and Henry V ([Kyoto]: [Showa Press], 1973), 6; E. M. W. Tillyard, Shakespeare's History Plays (London, 1944), 268-83.

${ }^{\text {Ixix }}$ For Machiavellian Hal, see Grace Tiffany, 'Shakespeare's Parables', Reformation, 16 (2011), 145-60 (149); Avery Plaw, 'Prince Harry: Shakespeare's Critique of Machiavelli', Interpretation: A Journal of Political Philosophy, 33.1 (2005), 19-43; John Danby, Shakespeare's Doctrine of Nature (London: Faber and Faber, 1961), 91.

lxx Tromly, 95-101; John Palmer, Political and Comic Characters of Shakespeare (London: MacMillan, 1962), 184-5.

${ }^{1 x x i}$ William Perkins, A Golden Chaine (Cambridge: 1600), [757].

lxxii John Andrewes, Andrewes Resolution to Return unto God by Repentance (London: 1621), 4.

lxxiii Calvin, 599. III.3.7.

${ }^{1 x x i v}$ Andrewes, Andrewes Resolution, 2-3.

${ }^{1 x x v}$ Ibid., 38-40.

${ }^{1 x x v i}$ Michael Davies, 'Falstaff's Lateness: Calvinism and the Protestant Hero in Henry IV', The Review of English Studies, New Series, 56.225 (2005), 351-378 (354).

lxxvii Paul A. Jorgensen, "'Redeeming Time” in Shakespeare's "Henry IV”, King Henry IV Parts 1 \& 2: A Casebook, ed. by G. K. Hunter (London: MacMillan Press, 1970), 231-42. lxxviii Perkins, Golden Chaine, 75[7]-8. 